\title{
Implanter Device
}

National Cancer Institute

\section{Source}

National Cancer Institute. Implanter Device. NCI Thesaurus. Code C149568.

Device for administering implants. 